\title{
Re-thinking the Mesolithic-Neolithic transition in the Iberian peninsula: a view from the West
}

\author{
Luiz Oosterbeek 1 \\ Instituto Politécnico de Tomar, Landscape Management Department, Estrada da Serra, Tomar \\ loost@ipt.pt
}

\begin{abstract}
Paper focuses on Mesolithic-Neolithic transition in the Iberian Peninsula by critical review of avaliable concepts and models. The obvious diversity of archeological record is taken as a strating point. Transition in this perspective is not seen as uniform and sudden economic or demographic change but as a slow political process, where different regional groups would have been forced to share the innovations while keeping their differences.
\end{abstract}

IZVLEČEK - Članek obravnava prehod iz mezolitika v neolitik na Iberskem polotoku s kritičnim pretresom obstoječih modelov in konceptov. Izhodišče je očitna raznolikost arheoloških zapisov. V tej perspektivi prehod ni hitra ekonomska in demografska sprememba, ampak počasen in asinhron politični proces, kjer različne regionalne skupine sprejemajo inovacije, a ob tem ohranjajo razlike.

KEY WORDS - Mesolithic; Neolithic; Iberia; "cardial model"; "shifting centres model"

To discuss the Mesolithic-Neolithic transition in Iberia implies, first, the defining of the concepts. By Neolithic, or Neolithisation, we understand a set of tendencies towards an increasing intensification of resources exploitation, demographic growth, complexity of economic relations, social differentiation, technological improvement and the generation of a new ideology. It was not inevitable, however, and the main question is not how it occurred (even if this is a basic assessment), but why it occurred. In this process, one must not avoid the fact that it implied not only economic or demographic growth, but, primarily for the human groups that were involved in it, it meant more work and increasing alienation. Therefore, it was also a political process. And, using Braudel's (1972) notions, if the long-term is measured by the preceding infrastructure variables, the short-term, decisive changes paid tribute to so- cial conflicts, political complexity and individual initiative. The archaeological record does not answer most of these aspects, but they remain essential, nevertheless.

In this sense, the "Neolithic" begins in the late "Mesolithic", the transition period. The evidence for this early stage in Iberia includes (see Oosterbeek 1994):

(1) the Muge-Cocina sequence, spanning the $7^{\text {th }}, 6^{\text {th }}$ and part of the $5^{\text {th }}$ millennia 2 . This is the "geometric" Mesolithic tradition. In the top layers of the Cave of La Cocina (Dos Aguas) and the Cabeço da Arruda shell midden (Muge), sherds of pottery relate to an evolved stage of the Neolithic;

(2) the Mallaetes sequence, not represented in Portugal, and dominated by a bladelets industry. Some

\footnotetext{
1 Director of Landscape Management Department and Professor of Prehistory at the Instituto Politécnico de Tomar, Estrada da Serra, P-2300 TOMAR. Email: loost@ipt.pt

2 The chronology discussed always refers to calendar years BC, based on termoluminescense or calibrated radiocarbon dates.
} 
authors relate it to a second Neolithic origin, without cardial impressed pottery;

3 the macrolithic Mesolithic, divided into different groups of unclear chronology (Asturian, Mirian, Ancorian or Languedocian). These groups do not overlap in space with the microlithic Mesolithic, but they have no clear relation with the earliest Neolithic assemblages. Two facts must be mentioned: the presence of pottery in macrolithic sites in Alentejo ( $\mathrm{Xe}$ rez de Baixo) and the Tagus valley (e.g. Amoreira, Monte Pedregoso), and the occurrence of macrotools in megalithic assemblages, which could indicate some sort of relationship (even if the megaliths are basically $5^{\text {th }}$ to $3^{\text {rd }}$ millenium phenomena);

(4) the sites with cardial impressed pottery. These are associated with other Neolithic improvements, and dominate some coastal areas such as the Spanish Levant, part of the Algarve, the Mondego estuary, with a few inland penetrations (Nabão and Almonda valleys, and an unclear site in the Alentejo), and minor occurrences associated with other types of pottery in other coastal areas (the Alentejo coast, the Sado estuary, Andalusia, north Africa). This spread has been traditionally related to the west Mediterranean Neolithic with cardial impressed pottery, but has also suggested speculation over the relation with the Mesolithic groups in Iberia, namely the Muge shell-middens;

5 the Neolithic sites without cardial impressed pottery that have a more variable distribution, primarily in the highlands in some areas (Andalusia), or coastal in others (Alentejo, Portuguese Estremadura), with some inland penetrations (like the Nabão valley). This group includes very old dated sites in Andalucia (e.g. Cueva de la Dehesilla), but also sites that are clearly older then the cardial impressed group, and some that have no clear chronology (Rio Maior, Alcobaça or Peniche);

(6) the earliest megalithic assemblages. M. Heleno (1956) identified and excavated a number of cistoid chambers, with microliths and polished stone, that were considered the earliest phase of the megaliths by V. Leisner (1967). None of these sites has been properly published, still less dated. However, they could date back to the late $6^{\text {th }}$ millennium, having a mainly inland distribution (like the megaliths of the $5^{\text {th }}$ millennium).

After the late $19^{\text {th }}$ and early $20^{\text {th }}$ centuries, attempts to identify the Neolithic in Iberia by L. Siret in 1890 and 1892 (the Almerian culture, after the site of $E l$ Garce), N. Delgado in 1884 (Cave of Furninha), N. Åberg in 1921 or Cartaillac in 1886, Bosch-Gimpera (1932) made the first synthesis, defining four "cultures": the Almerian, the caves group (with two subgroups, from Andalusia and Estremadura), the Portuguese (megalithic) and the Pirinean. Further developments by J. Martinez Santa Olalla (1941) established the first links with Africa: the Spanish-Mauritanian Neolithic (including the caves), and the Iberian-Saharan Neolithic (including the Almerian). Later, a similar approach was defined by J. San Valero Aparisi (1948).

The excavation and publication of the cave of Arene Candide in Liguria became a turning point for the study of the Iberian Neolithic. The author, B. Brea (1950), defined for the first time a model of Neolithic expansion from the east. According to him, the Neolithic had a fast and "Hellenistic" expansion, suggesting a migration of people from the east affecting coastal areas. The cardial pottery had oriental origins in Syria and Silicia (Tell Iudeideh, Ras Shamra, Mercin, Chagar Bazar, Arpachiyah, Ninive), Thessally (pre-Sesklo), Greece (Choirospilia), Corfu (Afiona), Montenegro (Crvena Stijena), Herzegovina (Zelena Pecina), crossing Italy and reaching Corsica, Liguria (Arma dell' Aguila, Arene Candide), Southern France, Catalonia and the Spanish Levant. The penetration inland was thought to be slow, this group hardly reaching the south and west of Iberia, with few exceptions. The strong Mesolithic tradition of sites like Coppa Navigata in Italy would indicate local groups' interactions with Neolithic sailors.

This new approach would lead, in the late 1950's and early 1960's, to the definition of several colonisation theories, from the early Neolithic to the Chalcolithic. Meanwhile, the research provided deep stratigraphies for the whole Neolithic process, in sites like Cueva de la Cariguela (Andalucia), Cova de l'Or (Alicante) or the Muge shell middens. Interest in the problem of navigation in the Mediterranean related to the introduction of Neolithic innovations has been a subject for continuous research. The distribution of obsidian is, for the central and eastern Mediterranean, a direct form of evidence. Such evidence does not exist for Iberia, and contacts by sea with the Maghreb or other parts of the Mediterranean, before the Chalcolithic, remain hypothetical. For instance, G. Camps (1982) used decorative patterns to stress that the presence of cardial pottery in the Maghreb (Achakar group, Idols Cave, El-Khril caves, Gar Cahal and Caf That el Gar), always coastal, 
stands for contacts with Iberia, at an epicardial stage, likely with the Levant (and not Andalusia), whereas another group (Oran), would relate to Andalusia, with impressed and grooved pottery, not cardial.

Regardless of the means of distribution, the diffusionist model dominated the 1960's, and it remains one of the most widely accepted views. Among these, the wave of advance model of Ammerman and Cavalli-Sforza (1971) is one of the most coherent. It measured those items in a chrono-geographical frame, taking Jericho as the presumed original centre, and defining the west Mediterranean as an area dominated by impressed pottery that could be even older than domestication itself.

From the late 1960's on, following on the one hand the new approaches to territorial analysis, and on the other, the papers of the New Archaeology, namely C. Renfrew (1979) (even if concerning later periods), explanatory models of the Neolithic started to be built with greater tribute to the interaction of all areas of human behaviour (technological, economic, social, ideological), with each other and with the environment, while regional studies became a priority of research.

Not much is known about the environment in this period. Following isolated studies, one may assume that after a colder phase, the weather became warmer and more humid. The sea level was higher than it is today. The soils were covered by a forest of $P i$ nus spp. and Quercus spp. trees, with a rich fauna. From the archaeological assemblages, it is known that hunting was still of major importance in the early Neolithic (including for species such as red deer, wild pig, wild cat, lynx, etc.). The earliest Neolithic sites, like Cova de l'Or, indicate a dietary change from proteins to carbon-hydrates. Some Neolithic sites (Caldeirão, Or) indicate, from the start, full domestication, but others (Nerja) suggest animals were domesticated before plants, and all sorts of possibilities may be found.

The vast majority of early Neolithic sites studied with stratigraphy are caves. In Portugal they are in most cases burial assemblages, although habitats are known from open-air sites (Vale Vistoso, Vale Pincel, Salema, Forno da Cal, Várzea do Lírio, etc.). What is known indicates a pattern of estuary or riverine groups of round or oval huts, without natural or artificial defences, corresponding to a still mobile settlement (seasonal?), unlike the east Mediterranean villages.
J. Guilaine (1996) points to the fact that these sites could be associated with an economy dependent on exploiting marine resources. Economic data is still limited, however, and an evaluation of these sites must still be based on other criteria. I believe that the very early Neolithic with cardial impressed pottery reached the interior at a later stage, as may be recognised in Alcobaça (and, one could add, Tomar or Torres Novas). A second phase of the Neolithic would then include sites like the cave of Furninha (Peniche), Bocas I (Rio Maior), Casa da Moura (Cesareda), the shell midden of Cabeço do Pez (Sado estuary) or Lapa do Fumo (Sesimbra). This phase, combining heavy decorated pottery (impressed, sometimes with cardium, with incised, plastic decoration) would be parallel, in the $5^{\text {th }}$ millennium, to early megalith building, this one dominating the inland areas). Guilaine also notes strong relations between this group and the Andalusian Neolithic, and speculates on defining the origins of each of the identified groups. All in all, Guilaine proposes a model for the western Mediterranean where each region integrates itself in the world of food producers by means of its own specific process, depending on several variables (location, resources, soils potential, the characteristics of the local Mesolithic, the ability of the groups to accept certain acquisitions, etc.), even if this does not imply a multitude of original Neolithic focus. He interprets the persistence of lithic traditions and the variability of pottery types and decorative motifs as evidence for these regional groups. In this sense, the similarities between different groups in the French Midi, Andalusia or Portugal, throughout the whole Neolithic, would stand for a general evolutionary tendency, rather than for a single phenomena.

The problem of the origins of the Neolithic become even more complex with the set of sites without cardial that have been dated in the southeast from the $7^{\text {th }}$ and $6^{\text {th }}$ millennia: Cova Fosca de Castellón, Abrigo Grande 2 del Barranco de los Grajos, (Murcia), Cueva del Nacimiento (Jaen), Cueva de Nerja (Malaga), Cueva Chica de Santiago (Sevilla), Cueva de la Dehesilla (Cadiz). They have incised, corded and grooved pottery, sometimes painted (almagre, ocre, magnesium), but rarely impressed (and never cardial), blades, bladelets, rare geometric microliths, a poor bone industry, few ornaments, and domestications associated with hunting and gathering. These dates, still controversial for some archaeologists, but which are tending to be more and more coherent and numerous, prove that this early Neolithic is, at least, as old as the cardial group. It should be noted 
that these sites, although broadly coastal, are actually in the highlands (Sierras). This is also the case for most early Neolithic sites without cardial pottery in Portugal.

A discussion of the origins of the Neolithic in Iberia can not ignore the evidence from north Africa, which lies $13 \mathrm{~km}$ south of Gibraltar. A. Gilman (1974) identified two major groups that could relate to Iberian assemblages: Oran and northern Morocco. In Oran, early Neolithic site with an assemblages close to the Iberian early Neolithic, with impressed non cardial ware, provided radiocarbon dates from the mid $6^{\text {th }}$ millennium (Cimitiere des Escargots) and the $5^{\text {th }}$ millennium (Deux Mamelles), whereas in a related inland site (Columnata) two $5^{\text {th }}$ millennium dates have been obtained. There are no absolute dates in northern Morocco, but there is a stratigraphic layer with cardial impressed and grooved ware (Achakar, Caf Taht el Gar) (Jodin 1959). Stressing the problems of dating and the stratigraphic reliability of the Moroccan sites, Gilman also underlines the difference of decoration patterns between these and Andalusia: the difference of composition and virtual absence of the cardial in Andalusia, the dominance of rocker-stamping in Tangier (rare in Andalusia), the dominance of linear impressions in Andalusia (rare in northern Morocco), and the much later occurrence of the grooved ware in Iberia. Therefore, apart from an eventually vague relation to the impressed ware of the west Mediterranean, no clear links could be established with Iberia.

The Iberian Neolithic, at least in the southeast, would have been associated with irrigation works. Gilman underlines the absence of a significant difference in the early Neolithic assemblages in different areas of Spain (dry and humid), that suggests that in dry areas, the lack of water was balanced by "regadio" (irrigation), which became very important in the social process.

The approach by G. Camps (1982) uses basically the same evidence as Gilman, but draws different conclusions. He considers the differences of cardial and impressed ware from northern Africa and Iberia within the variability of the epicardial complex, although agreeing with a greater proximity to the Levant than to Andalusia. However, he maintains that the Oran pottery belongs to a different tradition of incised, impressed and grooved ware, with good typological and chronological relations with Andalusia (Murciélagos, Nerja) in the $6^{\text {th }}$ millennium.
After Gilman's (1975) research, the excavation of $\mathrm{Ma}$ Izza in Atlantic Morocco, provided an interesting stratigraphy. There, Berthélémy and Accart (1987) recognized an early Neolithic layer with cardial impressed and incised pottery, under another layer with grooved ware. This is curious for two reasons: first, it is an unsuspected area for the occurrence of cardial pottery; second, the impressed and incised ware precedes the grooved ware. Also, both layers are pit burials, dug and reinforced with stones. This pattern is not very different from what is to be observed in many Iberian regions in the $5^{\text {th }}$ millennium, and makes us rethink the problems of stratigraphic interpretation of El-Khril, Gar Cahal and other Northern Morocco sites.

According to J. Lewthwaite (1986), the transition to the Neolithic in the west Mediterranean was slow, due to a system where seasonal crops became complementary to hunting and gathering, together with sheep and goat-herding. The village mode of social organisation was not adopted, and macro-tools continued to be used. This "contradiction" could be a result of animals, as well as pottery, being prestige goods. Also, the islands may have worked as a filter of the eastern Neolithic package, due to the restrictions of the insular landscapes and environment.

Considering an older Neolithic in the Italian peninsula, Lewthwaite proposed three processes of diffusion that could have taken place. The first is the traditionally accepted European coastal one, bearing a major Cardial/Ligurian influence. The second would reach Iberia following an open sea voyage, for which evidence is found at early Neolithic island sites. The Neolithic package in these islands would be adapted to the natural conditions of the islands, namely steep mountains, thus being filtered to the profit of pastoralism over agriculture, this filtered version being that which reached southern Iberia. A third model implies a north African diffusion from Italy to Tunisia (which does not imply more than $70 \mathrm{~km}$ by direct sea route), passing through Morocco before reaching Iberia or not. These alternative routes would explain the existence of two types of the earliest Neolithic in Iberia.

Following similar reasoning to Guilaine's, but integrating the newly dated sites, M. Pellicer and P. Acosta (1982), discussed the possibility of different natures for the two main early Neolithic groups: the Cardial (from the Levant) and the Andalusian (from Dehesilla, Mujer, etc.). The former could be a direct result of the impact of the Southern France cardial, 
whereas the later could be of local origin to a greater extent, becoming powerful enough to influence other areas of Iberia, such as the Spanish Meseta or Portugal.

In this discussion, the radiocarbon dates tend to be a major concern of many scholars. Based on the recent studies of important sites from the Levant, such as Cova de l'Or, Cueva de la Sarsa and Cova de les Cendres, M. Oliver (1987) considers two stages in the Early Neolithic, a cardial and an epicardial, the latter being different from the French, and characterized by the rarity of the cardial impressed pottery, and a general decay in the quality of the fabric and decoration of potteries. Both stages would date from the $6^{\text {th }}$ millennium, this epicardial also corresponding to the early Neolithic layers of sites from the Levant and Andalusia (thus refuting the $7^{\text {th }}$ millennium dates obtained for some of those sites).

After their research on the early Neolithic sites of Sines in the Alentejo coast (Vale Pincel I, Salema, Vale Vistoso), Tavares da Silva and J. Soares (1987) identified two Early Neolithic layers that they consider both excluded from the cardial network, and relates to the Andalusian Neolithic, namely Cueva de los Murcielagos. While agreeing with Marti, they consider also the possibility of two separate Neolithic processes with a similar chronology, the non-cardial being of major importance in Andalusia and Portugal.

These assemblages, together with the Sado estuary, have been the basis for J. Arnaud (1982) proposing two alternative models. Model A considers a first phase of the Mesolithic population in the mid-Sado valley, with episodic incursions to the coast or the interior in critical periods. A second phase would correspond to a mobile frontier between these Mesolithic people and the newly arriving Neolithics, which would nevertheless retain fishing and hunting as the main subsistence activity. Sedentism and agriculture would generate population growth, the occupation of the best agricultural lands (without the abandonment of others) and the gradual disappearance of the mobile frontier. The final phase would correspond to the emergence of proto-megaliths (cists). Model B considers for the first phase a seasonality of occupation of coastal (Autumn-Winter) and mid-Sado (Spring-Summer) sites, followed by the arrival of Neolithic innovations, when the shell-middens would still have been seasonally occupied by part of the population, the majority of which would settle in the coast, combining hunting, fishing and farming (Vale Pincel 1, etc.). Phase 3 would still have the occupation of the middens, the lithic variability indicating the specialization of the sites. The last phase would be similar to model A, thus considering the megaliths as a result of coastal population growth and subsequent occupation of the interior.

R. Chapman (1988) discussed these views, suggesting the possibility that the major population concentration was already to be found inland (Alentejo), due to the problems of diseases and flooding in the estuaries. He refused to see long-distance interaction as a major stimulus for complexity, as well as the implication that similar structures in distant areas are indicative of that interaction.

Pushing further the approach to regional variability, S. Jorge (1990) pointed out that the fitness of some Mesolithic groups prevented Neolithic improvements until the late $5^{\text {th }}$ millennium. It would be the case of the shell-middens of the Tagus and Sado estuaries, which relied on the marine and terrestrial resources. This author suggests differences within this broad strategy between the two areas, the Muge sequence, including large mounds that indicate several generations of occupation (apart from the visual impact of these middens), with a richer assemblage of lithics (microliths of Mediterranean type, including strong regional variants), antler and bone, whereas the Sado middens are smaller and without typical regional artifacts. The marginal occurrence of pottery in the top of the Muge sequence also would contradict the Sado acceptance of this item and point to a greater persistence of the Mesolithic in the Tagus valley.

I would note, at this stage, that the importance of marine resources was not merely coastal, as the cave Mesolithic shell-midden of Lapa do Papagaio (near Fátima) proves. This site also has the importance of drawing our attention to the complexity of exchange routes between coastal and inland areas, as early as the $9^{\text {th }}$ millennium, since it is a huge cave shell midden, $40 \mathrm{~km}$ inland, at the top of the limestone massif: clearly a ritual site, indicating a very complex behaviour pattern.

Entering the debate concerning the origin of the Neolithic, S. Jorge (1990) stressed the distinction between the Alentejo sites, with rare cardial pottery, and those at Mondego, Estremadura and Ribatejo, much closer to the cardial of the Spanish Levant. This picture suggests "influences" from different Iberian groups over the first Neolithic populations of Portugal (that are also contemporary with the Meso- 
lithic shell middens, and without stratigraphic continuity). Following Zvelebil's and Rowley-Conwy's model (1986), S. Jorge considered that the second half of the $6^{\text {th }}$ millennium could correspond to the availability phase, with a network of information uniting both Mesolithic and Neolithic populations. Only in the late $6^{\text {th }}$ and in the $5^{\text {th }}$ millennium would one observe the substitution phase, with less coastal and increasingly inland sites (towards soils with higher arable potential), the occurrence of Neolithic items in the Sado and Muge shell-middens (pottery and lithics, as in the layer III of Cocina), new artefact types (retouched blades and bladelets, an increasing number of polished stone tools, incised and plastic pottery decoration, and domestic animals. From this process would eventually emerge, in the $5^{\text {th }}$ millennium, the first proto-megaliths.

As I have mentioned, apart from details, there are the two basic theories explaining the origins of the Neolithic in Iberia. Whereas some, although interested in the local and region variability, stress links with the Mediterranean, others take this variability as a starting point.

It is obvious the basic problem, on which everyone agrees, is the lack of evidence to unscramble what J. Lewthwaite (1952) called the "cardial disorder". If one removes from the record all sites that did not have good stratigraphies or were badly excavated, one might end up with very few, or close to none. Tomar provided probably the best Portuguese sequence for the early Neolithic, and I think its study casts new light on the issues considered above.

One aspect seems to be accepted by all the models mentioned: the extreme variability associated with elements of resemblance. Everything points to a mosaic of groups that, although keeping their differences, do share a similar path. C. Runnels and T. H. van Andel (1982) proposed the existence of an information network born of the need for information about unstable weather, different resources, etc., which generated a centre/periphery relation in the Holocene. In fact, this unity/diversity dialectic is already present in the Mesolithic, in the relations of Moita do Sebastião and Cocina I, and the affiliation of the Cocina sequence with the Sauveterrian and Castelnovian complexes.

It has been discussed to what extent the early Neolithic represents a major break with the Mesolithic. As we have mentioned, scholars have recognised the importance of the Mesolithic tradition in the early
Neolithic assemblages, even if they differ in its interpretation. From our point of view, it is clear that there is not a moment of simultaneous discontinuity (as the synchronic sequences of the shell middens and early Neolithic sites indicate), but the introduction of a new socio-economic structure, even if marginal at first, which marks a change in the generic process. The different regional groups would have been forced to share the innovations.

This, however, is still a period of economic variability, social continuity and political dispersion. It only announces a new cycle of increased differentiation which becomes clear in the $4^{\text {th }}$ millennium.

The two basic perspectives are conditioned by various theoretical plans. On the one hand there are authors who understand the Neolithic process pre-eminently as a phenomenon of alogeneous origin, and for whom the Neolithic and Mesolithic concepts are, fundamentally, diverse. Following the pioneer work of J. Guilaine and V. Ferreira (1970), the main defender of this perspective, which we will call the "cardial model", is J. Zilhão (1992).

The coherence and simplicity of the diffusionist perspective is not to be found in the other perspective. In fact, the Mesolithic and the Neolithic, especially in their long-lasting coexistence, may be conceived as fundamentally associated, or as a single and integrated complex system. Various models may derive from this perspective, expressed in the defence of the originality of some contexts, or in the search for polygenetic origins for Neolithisation, or still in the refusal to accept the cardial ceramics or any other item (including the domesticated fauna and flora) as a major indicator.

The defenders of the first perspective try to emphasise the clarity of their statements, disdaining the apparent "confusion" of the remaining. They say that in science we proceed with univocal statements, and that their proposals are supported by irrefutable documents. Furthermore, they try to emphasise the archaeo-graphic weakness of their "opponents" (Guilaine 1996; Zilhão 1997).

As defenders of a dialectical and plural view of the Neolithic process, with this contribution we want to emphasise two essential aspects: the archaeo-graphic basis of the cardial model can not be understood in a univocal way; and theoretical simplicity does not allow an explanation of important "irregularities" in the archaeological record. 
Let us take, for example, the problem of the Mesolithic/Neolithic transition in Western Iberia, and particularly in the Alto Ribatejo. The "Alto Ribatejo" (North Ribatejo) is a region of central Portugal, characterised by the merging of three different geo-morphological units: the limestone massif of Estremadura, to the west; the Miocene basin of the Tagus, with its quaternary terraces, to the south; and the granites and schists from the "Beiras", to the east (which will form the Spanish "Mezeta"). It is a region that finds its unity in the diversity of landscapes and natural and cultural resources, and through the connection of the main rivers (the Tagus, Zêzere and Nabão) that constitute a sort of skeleton of the region.

Several sites (see Cruz 1992; 1993; 1995; 1997) related to the Mesolithic and early Neolithic have been excavated in this region: Povoado da Amoreira (Mesolithic/Early Neolithic), the open-air site of Santa Cita (Mesolithic) (Bicho 1997.10-29), several caves with early Neolithic burials (Gruta do Caldeirão, Gruta de Nossa Senhora das Lapas, Gruta do Almonda) and an early passage-grave (Anta $1 \mathrm{de} \mathrm{Val}$ da Laje) (Drewett et al. 1992).

The Gruta do Caldeirão was the subject of a very detailed and well presented monograph in 1992 by J. Zilhão, who has built from it a Portuguese version of the "cardial model" (Zilhão 1992).

In short, the earliest Neolithisation of western Iberia would have taken place in Estremadura, as a new colonisation of a type of ecosystem abandoned by people since the end of the upper Palaeolithic, by groups already adapted to the new agricultural and pastoral economic model. The Estremadura, uninhabited, would have been available for this change and would have constituted a "cardial" enclave, around which the Mesolithic shell middens would persist. Different ecosystems would correspond to various economic models, accepting the Neolithic process as a colonisation beginning in the littoral.

In this model, the key element is the evaluation that is made of other sites attributed to the early Neolithic in the Iberian Peninsula. J. Zilhão systematically questions the validity of the interpretation of stratigraphic sequences in various Neolithic places in Spain, and continually valorises the contexts with cardial ceramics, particularly the "Cova de l'Or". Actually, this methodology, extends to several sites in Portugal; this is how J. Zilhão and A. Carvalho (1998), initially leave out sites like Nossa Senhora das Lapas (with a dated context very similar to the non- cardial early Neolithic of the Gruta do Caldeirão (Oosterbeek 1993)), or like Set (conjunto) 4 of Buraca Grande (excluded because of not have decorated ceramics), while dates without closed stratigraphic contexts are included, like those from the Algar do Picoto or from the Casa da Moura. This is, as one may notice, a clear option: preferring the model rather than the "pressure" of the archaeological record; valorising evidence according to the pre-defined model.

In the same work from 1995 the conclusion is repeated: the absence of Mesolithic sites similar to the Muge industries (except for Forno da Telha, in Rio Maior) would confirm the secondary character of the human settlement in Estremadura during that period. It is that the authors indicate, regarding open-air sites, the predominance of quartz and quartzite industries over flint and chert, without establishing, nevertheless, their correlation, which I consider more logical, with pre-Neolithic industries of an identical nature.

A similar approach, with the recurrent use of the notion of a hiatus between the Epipaleolithic and the early Neolithic, is made by J. Guilaine, who was, in fact, the first author responsible for the modern introduction to Portugal of the "cardial paradigm" (Guilaine and Ferreira 1970). In his recent revision of the Neolithic process in the western Mediterranean, Guilaine (1996) argues against "very low Epipaleolithic dates" and "very high dates for ceramic contexts", suggesting a hiatus in the sequences of Araguina Senola ( Corsica), of Corbeddu (Sardinia), or of several, Andaluzia sites, while subscribing to Zilhão's model of Portugal.

It happens that the cardial model, presented in various publications, is an excellent example of an induction exercise, whose limited overtaking we discussed elsewhere. On a pure theoretical-methodological basis, in its extreme version as offered by J. Zilhão, it is a model that argues from a theory based on one site (the Gruta do Caldeirão, in spite of mentioning others), against theories that are landscape and multi-site based. Alternatively, J. Guilaine bases his reasoning on a selection of "key sites", but the procedure is, in the end, the same. In order to do so, it questions all the remaining sites that are then grouped into two categories: those that, although even if without a clear stratigraphy, may be accepted (those that integrate, in the collection, cardial ware), and those that are considered as inaccurately excavated (those that, although having early 
absolute dates, or alleged stratigraphic sequences, do not have cardial ware).

What has been discussed requires a return to the question of the Neolithic process model. Should we accept the priority of the diffusion mechanism, or of the evolutionary mechanism? I think this is a false question. I previously defended (Oosterbeek 1994) a multi-linear evolution model with what I called "shifting centres". It is, in a certain way, the same idea that V. Garcia (1997) proposes, after the notion of reciprocity between groups, by suggesting a Neolithic "capillarity" process, or from what we can deduce, although for a more recent period, from the study on the distribution of jadeite polished axes in Europe (Pétrequin et al. 1998). The most recent data, again, makes it difficult to separate, chronologically, the Early Neolithic (except for the pre-cardial layers) and even Middle Neolithic occupations. There is a difference in material culture, but there is a superimposition of dates, and there are no arguments strong enough to make the option in favour of a chronological, rather than geographical or "cultural" differentiation. The choice of identifying a "first stage" of the Neolithic process, grouping all this evidence, suggested by A. R. Cruz (1997), still seems, from an archaeological point of view, the most cautious.

The Neolithic process must have been a process without sudden discontinuities, marked by many inter-group articulation mechanisms, sharing a general tendency, but nevertheless without any of the elements of the so-called Neolithic package being indispensable; a process in which the novelties are accepted by some groups (as V. Garcia 1997 suggests), or socially imposed in some cases. In fact, when reading J. Guilaine's balance once again (1996), what seems to stand out is that the cardial model is limited to two areas (the French Midi and Valencia) and, above all, the fact that in the insular and southern contexts there are, frequently, very early dates for Neolithic contexts without cardial (!). However, it occurs that the type of model we are suggesting is not easy to test in archaeology. Ultimately, it is so diffuse, that archaeological evidence that could confirm or invalidate it will never be found. Is this a useless model, then? No! It simply belongs to prehistoric and not to archaeological research. It is refutable and possible to test in the logical and palaeoanthropological comparison domain, and not in the contextual description domain.

We are again in a paradoxical situation which recalls Markosian's (1996) text: what is the best question we can ask about the Neolithic process? The obvious answer that the defenders of the cardial model support, as well as many of their opponents, is the question, "What is the best way of archaeographically testing the various hypothesis that are, or will be, generated concerning Neolithization?" But the best answer is: "The best way is to test them outside the archeographic field". So, the best question is not the obvious one, but the other, that we can only formulate correctly, as we are building the answers, which is, by redefining the truth criteria.

From this we infer that the problem of the Neolithic process is obviously not an archaeology problem, it is a prehistory problem. The basic epistemological error of the cardial models occurs from trying to answer in the archaeological field a problem that has little to do with it. Inevitably, it develops a strange relation with the archaeological record, and produces a hybrid in the strict sense of the word: even if occasionally endowed of internal coherence (which, as we have seen, is not always the case), it is incapable of breeding, and pernicious for the development of knowledge. Hence, it is in the prehistoric field that V. Garcia (1997) explains the Cova de l'Or as a social storage place, in an argument that we could also apply to the Gruta do Caldeirão. In the so-called "Early Neolithic" of Iberia, the absence of villages, in association with exogamic practices, has at least two elements of proof: in the archaeographic plan there is no evidence for the first; in the biological plan, the reproductive nexus would impose the existence of the practices derived from the second assumption. Consequently, we can revise certain emblematic sites of the Neolithic process, such as Gruta do Caldeirão, or Cova de l'Or, and some artefacts, like the cardial ceramics or bracelets made of Glycymeris glycymeris, as a further advance in the anthropisation of the landscape, similar to rock art. The absence of the village model, on the other hand, is the strongest argument against the idea of a rapid and finished Neolithic period. Contrarily to other elements of the "package", like cattle breeding or ceramics, agriculture brought about a dramatic break in the management of the communities' time. By tying them to the soil, it ordered and gave rhythm to people's behaviour, contributing to the alienation of a part of the community. This process certainly took a long time, and had to cope with much opposition. 


\section{REFERENCES}

ABERG N. 1921. La civilisation énéolithique dans la Péninsule Ibérique. Uppsala.

AMMERMAN A. J., CAVALLI-SFORZA L. 1971. Measuring the rate of spread of Early Neolithic farming in Europe. Man. $6: 674-688$.

ARNAUD J. M. 1982. Le Neolithique ancien et le processus de Neolithisation au Portugal. Le Néolithioque Ancien Méditérranéen - Actes du Colloque International de préhistoire. Montpellier, Éd. du C.N.R.S.

BERNABÓ BREA L. 1950. Il neolítico a ceramiche impresse e la sua difussione nel Mediterraneo. Rivista di Studi Ligure, vol. XVI(1-3): 25-36.

BERTHÉLÉMY A., ACCART R. 1987. Ma Izza, site néolithique marocain. Bulletin de la Société Préhistorique Francaise, vol. 84: 75-82.

BICHO N. F. 1997. A Escavação de Emergência do Sítio Paleolítico de Santa Cita/Tomar. Em busca do passado, 1994-1997: 10-29.

BOSCH-GIMPERA P. 1932. Etnologia de la Península Ibérica. Barcelona.

BRAUDEL F. 1972. The Mediterranean and the Mediterranean World in the age of Philip II. London, Collins.

CAMPS G. 1982. Les relations entre l'Europe et l'Afrique du Nord pendant le Néolithique et le Chalcolithique. Travaux du LAPMO - 1982.

CARTAILHAC É. 1886. Les âges préhistoriques de l'Espagne et du Portugal. Paris.

CARVALHO A. F. 1998. o Abrigo da Pena d'Água (Rexaldia, Torres Novas): resultados dos trabalhos de 1992-1997. Revista Portuguesa de Arqueologia, vol. 1(2): 39-72.

CHAPMAN J. 1988. From 'space' to 'place': a model of dispersed settlement and Neolithic society. C. P. T. Burgess C. Mordent, M. Maddison. Enclosures and defenses in the Neolithic of Western Europe. Oxford, B.A.R. -International Series.

CRUZ A. J. C. da 1992. Análise geoquímica da coluna de amostragem D (camadas A/B/C-Eb) da Gruta do Caldeirão. In Zilhão J. (ed.), Gruta do Caldeirão. $O$ Neolitico Antigo: 203-214.

1993. Estudo Geoquimico de Preenchimentos Sedimentares de Grutas da Estremadura com ves- tígios de ocupaç̃o humana pré-histórica. Lisboa, dissertação de Doutoramento (dact.).

CRUZ A. R. 1995. Amoreira:trabalhos de emergência no IP6. TECHNE-Revista da Arqueojovem, n־1. $28-37$.

1997. Vale do Nabão. Do Neolítico à Idade do Bronze, Tomar, CEIPHAR, col. ARKEOS, vol. 2.

DELGADO J. F. N. 1884. La grotte de Furninha à Peniche. Congrès International d'Anthropologie et d'Archéologie Préhistoriques à Lisbonne, 1880. Lisboa.

DREWETT P., OOSTERBEEK L., CRUZ A. R., FÉLIX P. 1992. Anta 1 de Val da Laje 1989/90 - The excavation of a passage grave at Tomar (Portugal). Bulletin of the Institute of Archaeology London.

GILMAN A. 1974. Neolithic of Northwest Africa. Antiquity, vol. 48: 273-282.

1975. A late Prehistory of Tangier, Morocco. American School of Prehistoric Research Bulletin. Peabody Museum.

GRIMALDI S. P. R., CRUZ A. R., OOSTERBEEK L. 1999. A geo-archaeological interpretation of some "Languedocian" lithic collections of the Alto Ribatejo (Central Portugal). In A. R. Cruz, S. Miliken, L. Oosterbeek, Peretto C. (eds.), Human Population Origins in the Circum-Mediterranean Area: Adaptation of the Hunter-Gatherer groups to environmental Modifications, série ARKEOS, vol. 5: 231-242.

GUILAINE J. (1996), La Neolithisation de la Méditérranée Occidentale. In R. G. Cremonesi, J. Guilaine, J. L'Helgouac'h (eds.), The Neolithic in the Near East and Europe, Forlé, XIII International Congress of Prehistoric and Protohistpric Sciences: 53-68.

GUILAINE J. and FERREIRA 0. da V. 1970. Le Néolithique ancien au Portugal. Bulletin de la Société Préhistorique Francaise, vol. 67: 304-322.

HELENO M. 1956. Um quarto de século de investigação arqueológica. O Arqueologo Portugues, vol. 3 (Nova Série): 221-237.

JODIN A. 1959. Les Grottes d'El Khril Achakar (Province de Tanger). Bulletin d'Archéologie Marocaine, vol. 3: 249-313.

JORGE S. 0. 1990. Dos Últimos Cacadores-Recolectores aos Primeiros Produtores de Alimentos. J. Alar- 
cão. Portugal das Origens À Romanização. Lisboa, Presença.

LEISNER V. 1967. Die Verschiedenen Phasen des Neolithikums in Portugal. J. B. Wolters. Palaeohistoria, vol. XII.

LEWTHWAITE J. 1986. The transition to food production: a Mediterranean perspective. In M. Zvelebil (ed.), Hunters in Transition. Mesolithic Societies of Temperate Eurasia and their transition to farming.

1992. Cardial disorder: ethnographic and archaeological comparisons for problems in the early prehistory of West Mediterranean. Le Néolithique Ancien Méditérranéen. Montpellier, Éditions du CNRS.

MARKOSIAN N. 1996. 0 paradoxo da pergunta. In $D i$ sputatio, vol. 1 (http://purl.inesc.pt/pub/disputatio).

MARTINEZ SANTA-OLALLA J. 1941. Esquema Paletnologico de la peninsula ibérica. Madrid.

MARTI OLIVER B. 1978. El Neolitico de la Peninsula Ibérica; Estado actual de los problemas relativos al proceso de neolitización y evolución de las culturas neoliticas. Saguntum, vol. 13: 59-98.

OOSTERBEEK L. 1985. Elementos para o estudo da Estratigrafia da Gruta do Cadaval (Tomar). Almadan, vol. 4/5: 7-12.

1993. Nossa Senhora das Lapas - excavation of Prehistoric cave burials in Central Portugal. Papers of the Institute of Archaeology, vol. 4: 49-62.

1994. Echoes from the East: the western network. An insight to unequal and combined development, 7000-2000 BC. Londres, University of London, PhD. Dissertation (2 vols.).

PELLICER M., ACOSTA P. 1982. El Neolítico antiguo en Andalucia Occidental. Le Néolithique Ancien Méditérranéen. Montpellier, éditions du CNRS.

PÉTREQUIN A.-M., PÉTREQUIN P., CASSEN S. 1998. La función de las hachas en el Neolítico. Mundo Cientifico $N^{\circ}$ 195: 68-73.

RENFREW C. 1979. Problems in European Prehistory. Edimburgh University Press.

RUNNELS C., van ANDEL T. H. 1988. Trade and the origins of Agriculture in the Eastern Mediterranean. Journal of Mediterranean Archaeology, vol. 1: 83109.
SAN VALERO APARISI J. 1948. La península Hispánica en el Mundo Neolítico. Madrid, Seminário de História Primitiva del Hombre.

SILVA C. T., SOARES J. 1987. Les Communautés du Neólithique Ancien dans le Sud du Portugal. Premières Communautés Payannes en Méditerranée Occidentale. Paris, Éditions du C.N.R.S.

SIRET L. 1890. Las primeras edades del metal en el S.E. de España. Barcelona,

1892. La fin de l'époque néolithique en Espagne. L'Anthropologie, vol. 4:

VICENT GARCIA J. M. 1997. The Island Filter Model Revisited. In Miriam S. Balmuth, A. Gilman, L. PradosTorreira (eds.), Encounters and Transformations. The archaeology of Iberia in transition: 1-13.

ZILHÃO J. 1987. A Gruta do Caldeirão (Pedreira, Tomar). Balanço de sete anos de escavaçóes arquelógicas (1979-1985). Algar, vol. 1: 29-38.

1992. Gruta do Caldeirão. O Neolítico Antigo. Lisboa, IPPAR.

1993. Gruta do Caldeirão (Pedreira, Tomar). Relatório técnico-científico dos trabalhos arqueológicos realizados em 1983. Lisboa, dact. para o IPPAR.

1997. Maritime pioneer colonisation in the early Neolithic of west Mediterranean. Testing the model against evidence. Poročilo o raziskovanju paleolitika, neolitika in eneolitika v Sloveniji 24. 19-24.

ZILHÃO J., ANTÓNIO M. F. CARVALHO 1995. O Neolítico do Maciço Calcário Estremenho. Crono-estratigrafia e povoamento. I Congrés del Neolitic a la Peninsula Ibérica, Gavá-Bellaterra, RUBRICATUM, n¹: 659-71.

ZILHÃO J., MAURÍCIO J., SOUTO P. 1991. A Arqueologia da Gruta do Almonda (Torres Novas). Resultado das escavações 1988-89. Actas das $V^{\mathfrak{a}} \mathbf{S}$ Jornadas Arqueológicas.

ZVELEBIL M., ROWLEY-CONWY P. 1986. Foragers and farmers in Atlantic Europe. In M. Zvelebil (ed.), Hunters in Transition. Mesolithic Societies of temperate Eurasia and their transition to farming. 